Outsourcing in the Innovation Process: Locational and Strategic Determinants

\author{
James H Love \\ Aston Business School \\ Aston University \\ Birmingham B4 7ET \\ United Kingdom \\ E-mail: j.h.love@aston.ac.uk
}

\author{
Stephen Roper \\ School of Management and Economics and \\ Northern Ireland Economic Research Centre \\ Queen's University Belfast \\ Belfast BT7 1NN \\ United Kingdom \\ E-mail: s.roper@qub.ac.uk
}




\title{
Outsourcing in the Innovation Process: Locational and Strategic Determinants
}

\begin{abstract}
There is now substantial evidence that locational and agglomeration influences can have a significant positive effect on innovation performance. Networking and boundary-spanning activities are also increasingly recognised as important contributors to innovation success. This paper attempts to discover whether these factors are linked: in particular, is there any link between plant location, agglomeration effects and the extent of outsourcing in the innovation process? Using data for a large sample of UK and German manufacturing plants we find that organisational and strategic factors play a much greater and more consistent role in shaping the level of outsourcing in the innovation process than locational influences. Strategic approaches to outsourcing may also have benefits in terms of the potential for plants to obtain economies of scope in the management or governance of outsourcing in the innovation process.
\end{abstract}

JEL codes: R1, R12

Keywords: Innovation, Outsourcing, UK, Germany, 


\section{Introduction}

Since Davelaar and Nijkamp $(1989,1992)$ there has been considerable interest in the impact of locational factors on firms' innovative activity. A central thesis underlying this research has been the idea that urban or metropolitan locations provide the most conducive environment for innovation due to agglomeration, information and human resource advantages (Oakey, 1984; Kleinknecht and Poot, 1992; Todtling, 1992). Shefer and Frenkel (1998), for example, in their recent work on Northern Israel, distinguish between the 'metropolitan' area of Haifa, 'intermediate' (i.e. suburban areas), and 'peripheral' (i.e. rural) locations. Their results suggest - that for high-tech businesses at least - a metropolitan or urban location does have substantial advantages for product innovation. Brouwer and Kleinknecht (1996), using Dutch data, also identified positive urban effects on some aspects on firms' innovative activity, while Harris and Trainor (1995) found that firms in urban locations in Northern Ireland were more likely to introduce new products than those elsewhere.

While these studies provide a clear indication of the potential importance of an urban or metropolitan location for innovation they provide little insight into the mechanisms through which any such effect might operate. One possibility is that firms operating in urban and non-urban areas might make differential use of external resources as part of their innovation activity. This is important because there is now substantial evidence linking firms' boundary-spanning activities to enhanced innovation performance ${ }^{1}$. The extensive literatures on geographical clusters (e.g. Porter 1990, Baptista and Swann, 1998), industrial districts and innovative milieux (see, for example, the discussion in Koschatzky, 1998, pp 387-388), suggest that geographical proximity may be important in the development of strong collaborative relationships in innovation, emphasising the spatial dimension of such boundary-spanning activity.

\footnotetext{
${ }^{1}$ For a review of earlier studies see Freeman (1991). More recent survey-based evidence comes from the Netherlands (Oerlemans et al., 1998), Sweden (Karlsson, 1997), Germany and France, (Koschatzky, 1998) and the UK (Love and Roper, 1999; Roper et al, 2000). Other evidence of the positive innovation effects of firms' networking activities come from firm or industry case study evidence. Gemser and Wijnberg (1995) for example consider the effect of horizontal networks among companies in Silicon Valley and in the Italian furniture industry, while Autio (1997) provides evidence for networking among new technology based firms. Contrary evidence is limited, although Gauvin (1995) finds no evidence of positive networking effects in a study of Canadian patents data.
} 
Despite its potential importance, the outsourcing decision in the innovation process has received relatively little attention. Significant exceptions are a series of papers focussing on the factors determining the use of internal versus external R\&D (Hertog and Thurik, 1993; Audretsch et al., 1996; Love and Roper, 2000) and a recent paper by Veugelers and Cassiman (1999) focussing on Belgian firms' choice of partners during the product innovation process. From a regional perspective, however, the Veugelers and Cassiman paper is limited as it makes no allowance for the potential influence of locational factors on the outsourcing decision. Veugelers and Cassiman also treat the innovation process as a single activity with firms facing a single strategic decision on external sourcing. In reality, however, the product innovation process comprises a number of diverse activities with very different risk-reward balances: product testing, for example, is a much more predictable and routine activity than, say, prototype development. In what follows we examine the outsourcing decisions of a large sample of innovative UK and German manufacturing plants. Our data enable us to be more specific than Veugelers and Cassiman (1999) and we focus on the factors affecting the outsourcing decision for seven separate activities in the product innovation process. In each case our primary interest is whether we can identify any agglomeration or locational effects on the outsourcing decision.

The remainder of the paper is organised as follows. Section 2 reviews the relevant theoretical literature and outlines the conceptual framework that underlies the empirical research. Section 3 describes the data used and the estimation method adopted. Section 4 describes the empirical results and section 5 summarises the main empirical conclusions and suggests some directions for future research

\section{Conceptual Framework}

Outsourcing represents the 'fundamental decision to reject the internalisation of an activity' (Gilley and Rasheed, 2000, p. 764). As such it involves a strategic decision either to substitute external sourcing for internal activity or to use externally provided activities to extend a firm's capabilities. Proximity between the purchaser and the provider of the outsourced activity may influence the outsourcing decision due to agglomeration or clustering effects or what the urban economics literature calls 
localisation externalities (Dobkins, 1996). These may influence the outsourcing decision by: impacting on the costs of the outsourced activity; influencing the governance or management costs associated with outsourcing (Viming and Globerman, 1999); or, by changing the risks associated with information asymmetry, bounded rationality and opportunism (Williamson, 1975). In the particular context of the innovation process, where outcomes are uncertain and contracts are likely to be incomplete, the latter of these may be particularly important. 'Clustering of some firms may, for example, facilitate outsourcing possibilities, contacts and information that would not be readily available with dispersion. Locating in a central area ... may help to create and support networks of co-production or sub-contracting that can be vital to R\&D activities, through the resource savings that they provide. Such outsourcing economies may be crucial to small and medium -sized enterprises, it can save resources ... and the patterns of trust and reciprocity that can develop from coproduction may also provide for a stronger relationship between $R \& D$ and productive performance' (Suarez-Villa and Rama, 1996, p. 1156).

Proximity may, for example, allow firms to make savings in the transportation necessitated by outsourcing, particularly where clustering of similar businesses leads to the development of specialised transport services. Clustering may also allow gains to be made from specialisation, the development of specialised support services and technical support (Suarez-Villa and Rama, 1996). Local knowledge or interpersonal networks may also increase the scope for outsourcing, as may the development of strong local supply chains or other forms of local inter-firm networks (e.g. Morgan, 1997). Governance or management costs may also be reduced as proximity can facilitate the personal contacts which motivate and support the development of trust (e.g. Hansen, 1990). In each case the potential for such proximity effects - or outsourcing economies - is likely to be greater in urbanised or metropolitan areas (e.g. Suarez-Villa and Karlsson, 1996; Suarez-Villa and Rama, 1996). This suggests our principal hypothesis, namely that plants in urbanised or metropolitan locations will be more likely to undertake outsourcing in the innovation process.

In conjunction with this principal hypothesis we also consider a series of complementary issues relating to the general impact on the level of external sourcing of the characteristics of plants, the markets in which they operate and their strategic 
choices in managing the innovation process. The first of these relates to the possibility of economies of scope in the management of outsourcing in the innovation process. Economies of scope are associated with assets which are not wholly specific and therefore transferable in use (Teece 1997), which may include human (i.e. knowledge) resources as well as physical assets. Where the managers of a firm have acquired expertise in the management of external relationships in one aspect of innovation, this implicit knowledge is potentially transferable into other areas of the innovation process, suggesting that firms outsourcing in one activity are more likely to be outsourcing in other activities.

Market conditions, particularly their impact on firms' ability to appropriate postinnovation returns, may also influence the advantages of undertaking innovation externally or in-house. Teece (1986), for example, draws a distinction between markets in which market structure, the nature of technology and the intellectual property rights (IPR) regime are such that appropriability conditions are 'tight' (i.e. leakage is limited and imitation is difficult) and situations where appropriability conditions are 'weak' (i.e. leakage is frequent and imitation is easy). Resource constrained firms (or in Teece's terms firms lacking certain 'complementary assets') will be more inclined to source external assets in market situations where appropriability conditions are tight and where the necessary complementary assets are in sufficiently competitive supply to offset the potential hold-up problem of small numbers bargaining (Veugelers and Cassiman, 1999, p. 67) ${ }^{2}$. In situations where appropriability conditions are weaker, by contrast, firms may have less ability to protect and exploit the property rights arising from the results of their research, and more reason to fear the possible dissipation of rents which may result from disclosure of R\&D findings by a research partner or subcontractor, especially where embodied human capital is employed (Teece, 1988). However, this will be more of an issue for some firms than for others. In order to protect their favourable positions, firms in highly concentrated markets, especially those firms which themselves have a high market share, will be particularly keen to prevent or delay the imitation by rivals which often accompanies innovation. One way of doing this is to carry out research

\footnotetext{
${ }^{2}$ Oerlemans et al. (1998) also find evidence that the use of internal and external resources by Dutch companies differs significantly between the sectors as defined by Pavitt (1984), i.e. between supplier dominated, scale intensive, specialised suppliers and science based sectors.
} 
in-house, lessening the risk of disclosure to rivals. Hertog and Thurik (1993) also highlight the fact that undertaking innovation activities in-house may also give a firm a valuable lead-time over its rivals in a concentrated market ${ }^{3}$. The suggestion is therefore that markets characterised by high levels of concentration, regulatory barriers to innovation and an unfavourable risk/reward balance for innovation are likely to be associated with a low level of outsourcing in the innovation process.

We turn now to plant-level factors which theory and empirical research suggests may affect the outsourcing decision. Plant size is an issue that has received significant attention (e.g. Acs and Audretsch, 1988 and 1993). Typically, it is argued that larger firms because of their greater financial and technological resources have material advantages but small firms have behavioural advantages associated with entrepreneurial dynamism, flexibility and responsiveness to changing market conditions (Rothwell and Dodgson, 1994). Hay and Morris (1991, pp. 470-1), for example, identify scale of operation as one of the principal determinants of R\&D productivity ${ }^{4}$. Economies of scale may arise from equipment indivisibilities, and from the ability of larger research operations to recruit more able staff. In addition, there is the possibility that a large rather than a small firm may more effectively manage a given level of R\&D expenditure. While this may appear to suggest that larger firms are therefore less likely to outsource elements of the innovation process than their smaller counterparts, Veugelers and Cassiman (1999) suggest that although larger firms may benefit from economies of scale in internal $R \& D$, the improved absorptive capacity induced by internal R\&D may also put them in a good position to benefit from external sourcing in $R \& D$. This suggests that the relationship between plant size and external sourcing is conceptually ambiguous, and is an empirical matter.

Other factors often thought to influence the cost-effectiveness of technical development activity are whether a plant is part of a larger group of companies and its nationality of ownership (Love and Ashcroft, 1999). Any advantage from group membership is likely to be related both to the position of the individual subsidiary

\footnotetext{
${ }^{3}$ Hertog and Thurik (1993) find evidence that in Dutch manufacturing high levels of sectoral concentration are associated with a low relative incidence of external R\&D at the firm level. A similar negative, albeit weak, relationship between industry concentration and external R\&D is also reported by Audretsch et al. (1996) (see, in particular, their estimated coefficients on the concentration ratio terms).
} 
within the group and to the strategy of the group in terms of technological development (Birkinshaw and Hood, 1998). Where there is complementarity, in either technological or market terms, between a subsidiary company and the rest of a group, access to group resources may reduce the net cost of undertaking innovation activities in-house. This, in turn, suggests that the opportunity to access resources within the group, with reduced contractual uncertainty and associated IPR difficulties, will mean that membership of a group of companies will be associated with lower transaction costs in intra-group transactions and the potential for increased internal economies of scale and scope, leading to a reduced likelihood of external (i.e. extra-group) sourcing for group plants. If, however, a subsidiary company has 'unique technical capabilities', or they are product specialists, group membership is less likely to be an important cost determinant (Egelhoff et al, 1998). In addition, there is the corollary of the argument used earlier for plant size, that the expertise gained in managing intragroup relationships may be a capability that can be further exploited by engaging in extra-group activities. Again, the issue must be resolved empirically.

Firms' ability and willingness to innovate, and their ability to identify, access and manage external innovation resources, will also depend strongly on their internal resources and aspirations (Oerlemans et al., 1998). In-house R\&D, for example, may assist firms to absorb new externally-generated knowledge and provide the basis for firms' participation in collaborative innovation projects (e.g. Cohen and Levinthal, 1989; Gans and Stern, 1997; Cockburn and Henderson, 1998; Veugelers and Cassiman, 1999). The implicit suggestion of a complementary relationship between in-house R\&D or technical development activity and external sourcing conflicts, however, with some more some recent empirical evidence. Love and Roper (2001), for example, provide evidence from European manufacturing plants that the intensity of in-house R\&D and innovation networking activities are negatively related, i.e. that external technology sourcing is a substitute rather than a complement for in-house development. The possibility of either a complementary or substitute relationship between plants' internal R\&D activity and external sourcing again suggests that the matter should be left to empirical testing.

\footnotetext{
${ }^{4}$ However, Acs and Audretsch (1991, p.57) argue that “...diminishing returns to R\&D are the rule."
} 
Other aspects of firms' internal resource base may also be important in determining the need for external sourcing during the innovation process. Mason and Wagner (1994) and others, for example, have stressed the importance of high grade human resources for innovation: “... even those firms who have no aspirations to do more than adopt innovations developed elsewhere now increasingly require the services of highly qualified engineers and scientists in order to identify and make use of relevant information if they are to have any hope of staying in touch with more advanced competitors" (Mason and Wagner, 1994, p. 68). This suggests that plants with constrained human and other internal resources and more ambitious innovation aspirations are more likely to engage in outsourcing during the innovation process.

\section{Data and Estimation Methods}

The primary purpose of the empirical investigation is to examine whether there are locational influences on plants' outsourcing decision in the innovation process which may reflect the impact of any agglomeration advantages, while allowing for market and plant-level effects on the outsourcing decision. More specifically, we estimate a logit model of the form:

$\operatorname{Pr}\left(O_{i j}\right)=\alpha+\beta_{0} L_{i}+\beta_{1} O_{i k}+\beta_{2} M_{i}+\beta_{3} S_{i}+\beta_{4} P_{i}+\varepsilon_{i}$

where $\operatorname{Pr}\left(\mathrm{O}_{\mathrm{ij}}\right)$ is the probability that plant $\mathrm{i}$ outsources activity $\mathrm{j}, \mathrm{L}_{\mathrm{i}}$ is a vector of locational variables, $\mathrm{O}_{\mathrm{ik}}$ is a set of dummy variables which take value one if plant $\mathrm{i}$ is outsourcing other activities in the innovation process for $\mathrm{j} \neq \mathrm{k}, \mathrm{M}_{\mathrm{i}}$ is a vector of market descriptors, $\mathrm{S}_{\mathrm{i}}$ is plant size and $\mathrm{P}_{\mathrm{i}}$ is a vector of other plant characteristics. Two sets of parameters are of key interest here both of which we expect to positively influence the probability of outsourcing: $\beta_{0}$, which reflects the importance of locational factors on the outsourcing decision; and $\beta_{1}$, which reflects potential economies of scope in the governance of outsourcing. Parameters $\beta_{2}, \beta_{3}$ and $\beta_{4}$ reflect the impact of other conditioning variables. 
Data for the estimation are taken from the Product Development Survey (PDS), a postal survey providing comparable information on the innovation activity of 1700 UK manufacturing plants and 1300 German businesses (see Roper et al., 1996; Love and Roper, 2001) $)^{5}$. Plants responding to the PDS provided background information on the plant and detailed data on their product innovation activities during the 1991-94 period. Plants that had introduced either new or improved products over the 1991-94 period (i.e. 'innovators') also responded to a question relating to whether the plant was undertaking any outsourcing in seven activities of the product development process $^{6}$. These related to identifying new or improved products, prototype development, final product design/development, product testing and production engineering. Also included were related marketing initiatives, namely market research activity and the development of a marketing strategy for the new or improved products $^{7}$.

Table 1 summarises the proportion of innovating plants in each country outsourcing in each activity of the innovation process. Overall, a quarter to a third of plants were outsourcing in their innovation activities with significant differences evident between the UK and Germany for the proportion of plants outsourcing product testing and production engineering (Table 1, Part A). In the UK, the extent of outsourcing was typically above the German level, the exception being plants' market research. In their analysis of Belgian innovation data, Veugelers and Cassiman (1999) found a significant positive link between plant size and the probability of outsourcing in the innovation process. In Table 1 we therefore distinguish between small plants (i.e. those with less than 100 employees) and larger businesses. Like Veugelers and Cassiman we find a tendency for outsourcing to be more common among larger plants for each activity with the exception of production engineering (Table 1, Parts B and

\footnotetext{
${ }^{5}$ This was equivalent to a response rate of 23.7 per cent in Germany and 20.6 per cent in the UK (Roper et al., 1996, Table A1.1).

${ }^{6}$ See Roper et al. (1996), Love and Roper (2001) for a discussion of the factors that determine the probability of innovating using PDS data.

${ }^{7}$ Analysis carried out at the plant level rather than the firm level has some advantages. Although strategic decisions are likely to be carried out at firm level, they are implemented at the level of the individual plant, and are likely to be based on the product market situation faced by those individual plants. This is especially true of large multi-product enterprises. Thus a firm may choose to use an internal strategy at one plant and an external strategy at another in a different product division which is facing a quite different set of market circumstances, a subtlety which may be missed in firm-level analysis.
} 
C). Differences in the proportion of plants outsourcing between the UK and Germany also proved more significant for larger plants.

To isolate the potential effect of locational influences on plants' outsourcing decision, multivariate techniques are appropriate. In the case considered by Veugelers and Cassiman (1999), i.e. a single 'make' or 'buy' decision a simple logit model was appropriate. If, as here, however there is more than one choice variable (i.e. one for each activity) estimation becomes more complex. In a bivariate context, (i.e. where the plant is making a choice of whether or not to involve external organisations in two related activities), there are four alternative outcomes and standard estimation methods based on analytical results are feasible (Greene, 1997). Where, as here, the number of choice variables becomes larger, analytical approaches have until recently been seen as infeasible due to the necessity to evaluate high-dimensional integrals in the appropriate likelihood functions (Borsch-Supan and Hajivassiliou, 1993; Maddala, 1983). Recent software developments have made the estimation of multivariate Probit models with up to twenty choice variables feasible within standard econometric packages, such as Limdep. While such an approach has some advantages it also imposes a cost by excluding any observation for which information is missing on any variable. In the context of a postal survey like the PDS this proved to be a significant practical drawback, excluding from the estimation up to 20 per cent of cases from the choice equation for any individual activity of the innovation process ${ }^{8}$. On balance our preference is therefore for the simpler approach and in the next section we report single equation bivariate logit models for whether or not plants were outsourcing in each activity ${ }^{9}$.

\section{Estimation Results}

Tables 2 and 3 give the bivariate logit models for the UK, and Germany respectively for the probability that plants were outsourcing in each activity. Each equation includes variables designed to reflect the conditioning factors specified earlier

\footnotetext{
${ }^{8}$ For example, it proved possible to include only 540 observations in a multivariate Probit model estimated for all seven choice variables for the UK. This compares to 555-744 in the individual logit equations. Results for the multivariate Probit model for the UK are available on request from the authors.
} 
including a set of $0 / 1$ dummy variables reflecting whether or not the plant was outsourcing in other elements of the product innovation process ${ }^{10}$. The equations reported are the results of a general-to-simple modelling procedure, with variables excluded from the final equations where their t-statistic was less than one. Coefficient values reported are marginal values calculated at variable means for both the continuous and dummy variables. In general terms, the Chi-square values for each equation suggest that the logit models are a good representation of the underlying data with each equation significant at the one per cent level. The overall percentage of correct predictions achieved by the models is in line with other similar studies (e.g. Love and Roper, 2001) although there is significant variation between the various activities. The ability of the models to identify correctly those plants outsourcing in their innovation activity also varied significantly, being strongest in the early and later parts of the innovation process, and weakest for product testing and production engineering $^{11}$.

The first group of determinants of outsourcing included in the logit models are locational factors intended to capture potential agglomeration effects (e.g. Shefer and Frenkel, 1998). Initial estimation experiments included a number of locational indicators including per capita GDP, regional R\&D intensity and regional innovation intensity (see Data Appendix). In all cases these variables were wholly insignificant and are therefore excluded from the estimation results reported. Two other locational factors - population density and the level of government R\&D spending as a proportion of regional GDP - did prove significant in some outsourcing activities.

Even these variables, however, have mixed signs with government R\&D intensity, for example, being associated with increased outsourcing in the UK in product identification and market research but reduced levels of outsourcing in the design of marketing strategy. This provides little support for our principal hypothesis that metropolitan or urban locations have more extensive boundary-spanning opportunities

\footnotetext{
${ }^{9}$ In terms of the 'make or buy' distinction of Veugelers and Cassiman (1999), the choice considered here is between 'make' on the one hand and either 'buy' or 'make and buy' on the other.

${ }^{10}$ See the data appendix for variable definitions.

${ }^{11}$ Veugelers and Cassiman (1999) highlight an essentially similar issue in their analysis, pointing out that their multinomial logit model "under-predicts considerably the categories with limited frequencies: make only and buy only decisions. Nevertheless," they continue "the significant coefficients in the model estimation are interesting for identifying which variables are important in the organisation of the firm's innovation strategy" (p. 75).
} 
and are thus associated with higher levels of outsourcing during the innovation process.

Contrasting with the relative weakness of the locational influences, a notable feature of the estimated parameters is the strongly significant and (almost) universally positive signs on the set of dummy variables reflecting plants' outsourcing in other activities. The implication is that plants engaging in outsourcing in, say, market research are also likely to be working with external partners in product identification etc. This provides support for the contention that significant economies of scope exist in the governance of outsourcing in the innovation process. One implication of this result is that there is a potential for 'learning' by firms (and their partners) about the best ways to manage and conduct external relationships, and the implicit boundaryspanning knowledge transfers (Buckley and Carter, 1999; Mowery et al., 1996). Developing such effective co-ordination regimes or systems may help firms not only to overcome internal constraints on their innovation activity but also help them to reduce or respond more effectively to uncertainty. Co-operation may, for example, be important in reducing 'primary' uncertainty (i.e. volatility due to exogenous shocks), particularly where the behaviour of each partner was previously a major source of uncertainty for the other partner. Other advantages may arise from the development by partner organisations of routines designed to reduce 'secondary' uncertainty, i.e. the risk that unless there is co-operation of some form potential gains from combining the knowledge of each partner will be lost (Koopmans, 1957; Buckley and Carter, 1999).

The ability to generate these economies of scope in managing external relationships has been linked to the greater functional specificity which characterises the management of larger firms or plants, and larger plants' ability to absorb new knowledge. Indeed, in our data, outsourcing in the innovation process was notably more common among those plants with more than 100 employees (Table 1, parts B and C). In the logit models, dummy variables are included for plants in the 10-19, 20100 and 250 plus plant sizebands, with the estimated coefficients on these variables indicating the effect of plant size relative to plants in the 100-249 employee sizeband. If there is some systematic benefit of plant size in managing external relations we would therefore expect negative signs on the estimated coefficients for the 10-19 and 
20-100 sizebands and positive coefficients on the dummy variables for plants in the 250 plus sizeband. In fact, the estimated coefficients for plant size are relatively poorly determined and vary in sign for each plant sizeband. In the UK, for example, where plant size effects are stronger, outsourcing in production engineering was more common among smaller plants, while outsourcing market research was most common among plants in the 100-250 category (Table 2). Plant size effects were relatively weak in Germany with the strongest effects associated with market research, developing of plants' marketing strategy and final product development (Table 3).

In addition to plant size, previous studies have suggested a number of other plant specific factors that might be important in determining the extent of outsourcing. For example, in the logit models we include two dummy variables to indicate whether a plant is externally-owned and whether the plant is part of a multi-plant group. In both cases where the estimated coefficients on these variables are significant they take a positive sign. This provides some support for the idea that group membership may encourage rather than discourage a higher level of outsourcing in the innovation process. Other plant specific indicators relate to aspects of plants' internal resource base. In particular, considerable uncertainty exists a priori about the relationship between in-house R\&D activity and outsourcing in the innovation process. For the UK, however, the empirical evidence is unambiguous, with significant negative coefficients in the equations for prototyping and final product development. The implication is that, for these activities at least, in-house R\&D is acting as a substitute for outsourcing in the innovation process ${ }^{12}$. In Germany, our data suggest that inhouse $R \& D$ also acts as a substitute for outsourcing during the prototype and final product development stages of the innovation process, although neither effect is statistically significant (Table 3). The opposite effect is observed for product testing by German plants, i.e. German plants in our sample with in-house R\&D were more likely to out-source product testing than plants with no in-house R\&D capability.

Constrained internal resources may also necessitate that plants, particularly those in the smaller sizebands, source expertise externally during the innovation process. In the logit models we include a composite variable reflecting attitudinal barriers to

\footnotetext{
${ }^{12}$ See Love and Roper (1999) for further evidence of a substitute relationship between in-house R\&D activity and both intra and extra-group networking activity in the innovation process.
} 
innovation within the firm, any lack of information for innovation and any perceived lack of expertise. The expectation is that where internal constraints on innovation are greater the plant may have more incentive for outsourcing. Plants with more ambitious product innovation objectives may also have more necessity to source additional innovation resources externally. In the logit models we reflect this in two further composite variables reflecting plants' aspirations to improve the breadth and quality of their product ranges. None of these three variables, however, produces very satisfactory results with the estimated coefficients poorly defined and variable in sign. The weakness of these internal or aspirational factors reflects the earlier findings of Veugelers and Cassiman (1999) who note that "variables at the firm level relating to lack of opportunities, needs or information, fail to affect the sourcing decision" (p.75).

One clear possibility is that these firm or plant specific factors are dominated by market influences on the external sourcing decision. In the logit models we attempt to capture the effect of plants' market situation by including indicators related to sectoral R\&D intensity, plants' market share, plants' innovation objectives and composite variables related to competitive, financial and regulatory barriers to innovation. R\&D intensity is taken here to represent the extent of technological opportunity in the sector, i.e. the potential for achieving competitive advantage through innovation. Thus we expect that in high $R \& D$ intensity sectors the potential gains from innovation and - since boundary-spanning activities are positively linked to innovation - from outsourcing are greater than those in low intensity sectors. What we observe, however, is a more mixed pattern with high $R \& D$ intensity associated with higher levels of external sourcing in product identification, final product development and development of plants' marketing strategy in the UK but lower levels of outsourcing in plants' product testing, production engineering and market research activities (Table 3). Results for Germany are weaker with signs again mixed. In short, this suggests little clear relation between technological opportunity and the extent of outsourcing. Other market related variables are also weak with little evidence of any consistent influence from market concentration or barriers to innovation on the level of outsourcing.

Taken together these results provide little consistent support for either locational, resource constrained or market structure explanations for the extent of outsourcing in 
the innovation process. More consistency is evident between what might be considered organisational or strategic factors and plants' outsourcing decisions. In particular, in-house R\&D seems to be acting as a substitute for outsourcing in some activities and ownership links to other plants are also associated with an increased level of outsourcing. Both effects suggest that plants are 'managing' their portfolios of external links to a greater or lesser extent alongside other strategic decisions relating to ownership and the development of internal competencies. The potential gains from this type of strategic approach are also suggested by the potential economies of scope, or learning, by firms in the governance of their external relationships.

\section{Conclusions}

Our modelling of the determinants of outsourcing during the innovation process suggests two main empirical results relating to the general determinants of the level of outsourcing in each activity. First, despite considerable experimentation with a range of indicators our analysis provides little evidence for the suggestion that locational factors play any very significant role in determining the level of outsourcing in the innovation process. In this respect our results are closer to those of Love and Roper (2001) and Roper (2001) than, say, Shefer and Frenkel (1998). One caveat here is that the locational indicators we test for the UK and Germany relate to NUTS 2 regions and it may be that any locational effects which are operating are more spatially specific (although see Roper, 2001). Secondly, our results are consistent with neither a resource-constrained or market-structure explanation of outsourcing. In this respect our results are similar to Veugelers and Cassiman (1999), although they find significant plant size effects which we do not identify.

Organisational and strategic factors do, however, play a consistent role in shaping the level of outsourcing. In particular, we find some evidence of a substitution relationship between in-house $R \& D$ and outsourcing activity. We also find evidence that where a plant is a member of a larger group of companies, outsourcing is more common. One potential interpretation of these results is that firms are in effect 'managing' their portfolio of external relationships alongside the development of in- 
house innovation competencies. Our analysis also suggests that such a strategic approach may have some benefits in terms of the potential for economies of scope in the management or governance of outsourcing in the innovation process. These strategic and organisational factors far outweigh any locational or agglomeration influences.

These results contribute to our understanding of the more strategic elements of the make-or-buy decision in the product innovation process. Other elements of firms' innovation strategies remain largely unexplored, however. For example, how are collaborative partners selected and what monitoring and control mechanisms are used in these collaborations? How do national innovation policies, national differences in attitudes to the innovation risk-reward balance, and firms' boundary-spanning decisions interact? On the latter of these, some preliminary work does indicate that such national differences to exist, and do have an effect on product innovation strategies (Roper, 1997; Love, 2001); but further work, preferably employing panel data analysis to give some time dimension to the process, would greatly enhance our understanding of one crucial aspect of the product innovation process. 
Table 1: Percentage and Rankings of Plants Involving Other Plants or Organisations in Elements of the Product Innovation Process

\begin{tabular}{lccc} 
& $\chi^{2}$ & $\begin{array}{c}\text { UK } \\
\mathbf{\%}\end{array}$ & $\begin{array}{c}\text { Germany } \\
\mathbf{\%}\end{array}$ \\
\hline A. All Manufacturing Plants & & & \\
Identifying new products & $0.144(\rho=0.704)$ & 27.0 & 26.4 \\
Prototype development & $0.034(\rho=0.854)$ & 30.9 & 28.3 \\
Final product development & $0.130(\rho=0.718)$ & 26.2 & 25.5 \\
Product Testing & $21.374(\rho=0.000)^{* * *}$ & 31.1 & 14.1 \\
Production Engineering & $35.553(\rho=0.000)^{* * *}$ & 22.1 & 9.8 \\
Market Research & $1.451(\rho=0.228)$ & 30.3 & 34.2 \\
Developing strategy & $2.039(\rho=0.153)$ & 25.6 & 20.4
\end{tabular}

\section{B. Plants Employing 100 or less}

$\begin{array}{lccc}\text { Identifying new products } & 3.759(\rho=0.053)^{*} & 21.2 & 24.0 \\ \text { Prototype development } & 0.025(\rho=0.875) & 27.9 & 26.4 \\ \text { Final product development } & 0.670(\rho=0.413) & 23.2 & 25.1 \\ \text { Product Testing } & 13.761(\rho=0.000)^{* * *} & 30.1 & 13.1 \\ \text { Production Engineering } & 27.980(\rho=0.000)^{* * *} & 24.0 & 10.5 \\ \text { Market Research } & 2.285(\rho=0.131) & 24.6 & 32.3 \\ \text { Developing strategy } & 0.436(\rho=0.509) & 21.6 & 19.0\end{array}$

C. Plants Employing 100 or more

\begin{tabular}{llcc} 
Identifying new products & $4.747(\rho=0.029)^{* *}$ & 42.9 & 35.1 \\
Prototype development & $0.131(\rho=0.717)$ & 36.1 & 35.2 \\
Final product development & $2.882(\rho=0.090)^{*}$ & 30.2 & 26.9 \\
Product Testing & $8.362(\rho=0.004)^{* * *}$ & 32.2 & 17.5 \\
Production Engineering & $7.287(\rho=0.007)^{* * *}$ & 15.1 & 7.5 \\
Market Research & $0.500(\rho=0.479)$ & 44.9 & 40.6 \\
Developing strategy & $10.619(\rho=0.001)^{* * *}$ & 34.5 & 25.5 \\
\hline
\end{tabular}

Notes

1. $\chi^{2}$ tests given in table indicate the difference between Germany and the UK in the proportion of plants outsourcing in each element of the innovation process. $* * *$ indicates a significant difference at 1 percent, ** 5 per cent, * 10 per cent.

2. Table relates to manufacturing plants introducing any new or improved product from 1991-94 with 20 or more employees. Survey responses are weighted to give nationally representative results. Sample sizes differ between elements of innovation process due to non-response to some questions. Average sample sizes for parts A, B and C of the table are respectively: UK, 861, 391 and 375; Germany 840, 395, 445.

\section{Source PDS}


Table 2: UK Logit Models for External Activity in the Innovation Process

\begin{tabular}{|c|c|c|c|c|c|c|c|}
\hline & $\begin{array}{c}\text { Product } \\
\text { Identification }\end{array}$ & Prototyping & $\begin{array}{l}\text { Final Product } \\
\text { Development }\end{array}$ & $\begin{array}{l}\text { Product } \\
\text { Testing }\end{array}$ & $\begin{array}{c}\text { Production } \\
\text { Engineering }\end{array}$ & $\begin{array}{c}\text { Market } \\
\text { Research }\end{array}$ & $\begin{array}{c}\text { Developing } \\
\text { Marketing } \\
\text { Strategy }\end{array}$ \\
\hline Constant & $-0.663 * *$ & $-0.581 * *$ & -0.185 & $-0.703 * *$ & $-0.412 * *$ & $-0.698 * *$ & $-0.470 * *$ \\
\hline \multicolumn{8}{|l|}{ Locational Factors } \\
\hline Population Density & -0.152 & & & $0.150 * *$ & -0.069 & $-0.218 * *$ & \\
\hline Government R\&D Spend & $0.192 *$ & & & -0.065 & & $0.225 * *$ & $-0.230 * *$ \\
\hline \multicolumn{8}{|l|}{ Other External Activity } \\
\hline Product Identification & & $0.150 * *$ & $0.108 * *$ & & $0.088 * *$ & $0.239 * *$ & $0.113 * *$ \\
\hline Prototyping & $0.102 *$ & & $0.300 * *$ & & $0.151 * *$ & $-0.112 *$ & $0.090 * *$ \\
\hline Final Product Development & $0.162 * *$ & $0.437 * *$ & & $0.420 * *$ & & & $0.093 * *$ \\
\hline Product Testing & & 0.062 & $0.316 * *$ & & $0.120 * *$ & $0.234 * *$ & \\
\hline Production Engineering & $0.155 * *$ & $0.282 * *$ & $0.085 *$ & $0.228 * *$ & & & \\
\hline Market Research & $0.249 * *$ & & & $0.185 * *$ & & & $0.523 * *$ \\
\hline Developing Mktg. Strategy & $0.189 * *$ & & & & & $0.833 * *$ & \\
\hline Market Factors & & & & & & & \\
\hline Medium R\&D Intensity & & 0.053 & $0.065 *$ & & $-0.042 *$ & & \\
\hline High R\&D Intensity & $0.133 * *$ & & & $-0.090 *$ & & $-0.251 * *$ & $0.110 * *$ \\
\hline Market Share (Log) & 0.029 & & & & $0.020 *$ & & $-0.031 * *$ \\
\hline Market Objectives & 0.184 & & & & & $0.351 *$ & -0.152 \\
\hline Market Barriers & & & -0.208 & & & & \\
\hline Financial Barriers & -0.185 & $0.188 *$ & -0.095 & & $0.101 *$ & & \\
\hline Regulatory Barriers & -0.157 & & & & & & \\
\hline \multicolumn{8}{|l|}{ Plant Size } \\
\hline 10-19 Employees & & & 0.090 & & $0.204 * *$ & $-0.129 *$ & \\
\hline 20-100 Employees & & & -0.068 & $0.098 * *$ & $0.158 * *$ & $-0.136 * *$ & \\
\hline 250 plus Employees & -0.086 & & $0.091 *$ & & -0.053 & & 0.083 \\
\hline \multicolumn{8}{|l|}{ Plant Specific Factors } \\
\hline Externally Owned & $0.105 *$ & & 0.074 & -0.065 & $0.071 * *$ & & \\
\hline Multi-plant Company & $0.097 *$ & $0.140 * *$ & & & 0.040 & & $0.120 * *$ \\
\hline In-house R\&D & -0.062 & $-0.091 *$ & $-0.109 * *$ & 0.058 & & & \\
\hline Internal Barriers & $0.343 * *$ & & & 0.129 & & & \\
\hline Product Range Objectives & & & $-0.356 * *$ & 0.178 & & & \\
\hline Product Quality Objectives & 0.164 & & $0.204 *$ & & & & \\
\hline $\mathrm{N}$ & 555 & 700 & 612 & 639 & 614 & 744 & 661 \\
\hline Log Likelihood & -238.8 & -291.0 & -187.4 & -264.5 & -208.5 & -252.2 & -194.3 \\
\hline Restricted Log Likelihood & -354.6 & -442.5 & -359.7 & -381.8 & -296.1 & -488.5 & -404.4 \\
\hline Equation Chi-Square & 231.7 & 302.9 & 344.6 & 234.5 & 175.2 & 472.6 & 420.1 \\
\hline$\%$ correct total & 81.3 & 81.6 & 87.4 & 81.4 & 84.4 & 87.4 & 87.3 \\
\hline$\%$ correct external & 63.6 & 62.9 & 69.0 & 57.7 & 40.9 & 75.4 & 80.4 \\
\hline$\%$ correct in-house only & 90.2 & 90.7 & 94.4 & 90.8 & 94.4 & 94.3 & 90.3 \\
\hline
\end{tabular}

Notes: Coefficients given are marginal values calculated at variable means. ${ }^{* *}$ denotes coefficients which are significantly different from zero at the 5 per cent level, * denotes significance at the 10 per cent level. Variable definitions and sources are given in the Data Annex. Full estimation results are available from the authors on request. 
Table 3: German Logit Models for External Activity in the Innovation Process

\begin{tabular}{|c|c|c|c|c|c|c|c|}
\hline & $\begin{array}{c}\text { Product } \\
\text { Identification }\end{array}$ & Prototyping & $\begin{array}{l}\text { Final Product } \\
\text { Development }\end{array}$ & $\begin{array}{l}\text { Product } \\
\text { Testing }\end{array}$ & $\begin{array}{l}\text { Production } \\
\text { Engineering }\end{array}$ & $\begin{array}{c}\text { Market } \\
\text { Research }\end{array}$ & $\begin{array}{c}\text { Developing } \\
\text { Marketing } \\
\text { Strategy }\end{array}$ \\
\hline Constant & $-0.693 * *$ & $-0.481 * *$ & $-0.464 * *$ & $-0.384 * *$ & $-0.248 * *$ & $-0.429 * *$ & $-0.356 * *$ \\
\hline \multicolumn{8}{|l|}{ Locational Factors } \\
\hline Population Density & & 0.063 & $-0.055 *$ & & & & \\
\hline Government R\&D Spend & & -0.116 & $0.171 * *$ & & & & \\
\hline \multicolumn{8}{|l|}{ Other External Activity } \\
\hline Product Identification & & $0.224 * *$ & & $0.132 * *$ & -0.017 & $0.339 * *$ & $0.122 * *$ \\
\hline Prototyping & $0.244 * *$ & & $0.223 * *$ & & & 0.066 & \\
\hline Final Product Development & & $0.355 * *$ & & $0.221 * *$ & $0.032 * *$ & & \\
\hline Product Testing & $0.221 * *$ & & $0.243 * *$ & & $0.034 * *$ & & \\
\hline Production Engineering & & & $0.136 * *$ & $0.103 * *$ & & $0.271 * *$ & $0.137 * *$ \\
\hline Market Research & $0.256 * *$ & & & & $0.049 * *$ & & $0.371 * *$ \\
\hline Developing Mktg. Strategy & $0.233 * *$ & & & -0.039 & $0.047 * *$ & $0.722 * *$ & \\
\hline \multicolumn{8}{|l|}{ Market Factors } \\
\hline Medium R\&D Intensity & $0.084 *$ & & & $-0.048 *$ & & & \\
\hline High R\&D Intensity & -0.097 & $0.145 * *$ & -0.055 & & & & \\
\hline Market Share (Log) & & & -0.016 & & & & \\
\hline \multicolumn{8}{|l|}{ Market Objectives } \\
\hline Market Barriers & & $0.281 *$ & & & 0.073 & $0.440 * *$ & \\
\hline Financial Barriers & $-0.116 * *$ & & & & & & \\
\hline Regulatory Barriers & 0.124 & & & 0.088 & $0.045 *$ & & $-0.098 *$ \\
\hline \multicolumn{8}{|l|}{ Plant Size } \\
\hline 10-19 Employees & -0.094 & & $0.097 * *$ & & & & \\
\hline 20-100 Employees & & & & & 0.020 & $-0.177 * *$ & \\
\hline 250 plus Employees & 0.065 & & 0.061 & & & & $-0.072 * *$ \\
\hline \multicolumn{8}{|l|}{ Plant Specific Factors } \\
\hline Externally Owned & & -0.278 & & & & & \\
\hline Multi-plant Company & & $0.158 * *$ & 0.044 & 0.036 & & $0.101 *$ & 0.048 \\
\hline In-house R\&D & & -0.066 & -0.054 & $0.129 * *$ & & & \\
\hline Internal Barriers & 0.132 & & & -0.119 & -0.063 & & \\
\hline Product Range Objectives & 0.193 & & & -0.135 & $0.096 * *$ & $-0.310 *$ & \\
\hline Product Quality Objectives & & 0.153 & & $0.166 * *$ & & 0.139 & \\
\hline $\mathrm{N}$ & 615 & 665 & 676 & 614 & 612 & 680 & 757 \\
\hline Log Likelihood & -276.5 & -326.1 & -224.2 & -225.0 & -131.0 & -275.7 & -248.0 \\
\hline Restricted Log Likelihood & -386.4 & -408.3 & -342.1 & -297.0 & -168.3 & -453.7 & -430.0 \\
\hline Equation Chi-Square & 219.8 & 164.5 & 235.8 & 144.0 & 74.5 & 356.0 & 365.6 \\
\hline$\%$ correct total & 79.8 & 77.0 & 86.2 & 84.7 & 92.2 & 82.1 & 84.3 \\
\hline$\%$ correct external & 58.1 & 43.6 & 49.3 & 38.8 & 6.3 & 68.1 & 68.6 \\
\hline$\%$ correct in-house only & 90.2 & 91.6 & 95.7 & 95.4 & 99.5 & 90.9 & 89.7 \\
\hline
\end{tabular}

Notes: Coefficients given are marginal values calculated at variable means. $* *$ denotes coefficients which are significantly different from zero at the 5 per cent level, * denotes significance at the 10 per cent level. Variable definitions and sources are given in the Data Annex. 


\section{Data Annex}

Market Factors

Medium R\&D Intensity

High R\&D Intensity

Market Share (Log)

Market Objectives

Market Barriers

Financial Barriers

Regulatory Barriers

Plant Size

Plant Specific Factors

Externally Owned

Multi-plant Company
Dummy variable value 1 if plant is in Metals and Fabrication, (SIC92 27, 28), Mechanical Engineering, 29, Transport Equipment, 34, 35, and 0 otherwise. Source: Product Development Survey.

Dummy variable value 1 if plant is in chemicals, 24 , electrical \& optical equip., 30, 31, 32, 33, and 0 otherwise. Source: Product Development Survey.

Market share derived as ratio of plant employment to that in the 4-digit industry. Source: UNIDO database.

Composite variable derived as mean of Likert indices relating to importance of matching competitors, increasing market share and entering new markets as innovation objectives. Scaled to lie between 0 (unimportant) and 1 (very important). Source: Product Development Survey.

Composite variable derived as mean of Likert indices relating to importance of lack of opportunities and lack of partners as barriers to innovation. Scaled to lie between 0 (unimportant) and 1 (very important). Source: Product Development Survey.

Composite variable derived as mean of Likert indices relating to importance of riskiness, low expected returns and lack of innovation finance as barriers to innovation. Scaled to lie between 0 (unimportant) and 1 (very important). Source: Product Development Survey.

Variable derived from Likert indices relating to importance of regulation as barrier to innovation. Scaled to lie between 0 (unimportant) and 1 (very important). Source: Product Development Survey.

Plant employment in 1993. Source: Product Development Survey.

A dummy variable taking value 1 if the plant was owned outside the UK and 0 otherwise. Source: Product Development Survey.

A dummy variable taking value 1 if the plant was 
part of a group of companies and 0 otherwise. Source: Product Development Survey.

In-house R\&D

Internal Barriers

Product Range Objectives

Product Quality Objectives

relating to importance of developing environmentally

\section{Locational Factors}

Population Density

Government R\&D Spend

GDP per Capita

Regional R\&D Intensity

Regional Innovation Intensity friendly products and improving product quality as innovation objectives. Scaled to lie between 0 (unimportant) and 1 (very important). Source: Product Development Survey.

A dummy variable taking value 1 if the plants was undertaking in house R\&D and 0 otherwise. Source: Product Development Survey.

Composite variable derived as mean of Likert indices relating to importance of no information, lack of expertise and attitudinal barriers to innovation. Scaled to lie between 0 (unimportant) and 1 (very important). Source: Product Development Survey.

Composite variable derived as mean of Likert indices relating to importance of replacing products, extending the product range and reducing product cost as innovation objectives. Scaled to lie between 0 (unimportant) and 1 (very important). Source: Product Development Survey.

Composite variable derived as mean of Likert indices Product Development Survey.

Population densities at the level of the NUTS 2 regions. Source: Regional Trends, 1994, Table 2.1.

Government R\&D is the share of the labour force engaged in government R\&D in 1993 in NUTS 2 regions. Source: R\&D Annual Statistics (Eurostat) 1996, Table 15b.

Per capita relative to the EU average in 1991, NUTS 2 regions. Source: Regional Trends, 29, Table 2.1, p. 35 .

Mean percentage of workforce engaged in $R \& D$ 1994, manufacturing plants with more than 20 employees for NUTS 2 regions. Source: PDS.

Mean number of new and improved products introduced over 3 year period, 1991-93, manufacturing plants with more than 20 employees for NUTS 2 regions. Source: PDS. 


\section{References}

Acs, Z and Audretsch, D B (1991) 'R\&D, Firm Size and Innovative Activity', in Acs, Z J and Audretsch, B D (eds) Innovation and Technological Change, Harvester Wheatsheaf, Hemel Hempstead.

Acs, Z J and Audretsch, D B (1988) 'Innovation in Large and Small Firms', American Economic Review, 78, 678-90.

Acs, Z J and Audretsch, D B (1993) 'Innovation and Firm Size - The New Learning', International Journal of Technology Management, Special Publication on Small Firms and Innovation.

Audretsch, D B, Menkveld, A J and Thurik, A R (1996) 'The Decision Between Internal and External R\&D' Journal of Institutional and Theoretical Economics, 152, 517-30.

Autio, E (1997) 'New, Technology-Based Firms in Innovation Networks Symplectic and Generative Impacts', Research Policy, 26, 263-281.

Baptista, R and Swann, P (1998) 'Do Firms in Clusters Innovate More?', Research Policy, 27, 525-540.

Binks, M and Ennew, C (1996) 'Financing Small Firms', in Burns P and Dewhurst, J (eds.) 'Small Business and Entrepreneurship', London, Macmillan.

Birkinshaw, J and Hood, N (1998) Multinational Corporate Evolution and Subsidiary Development, Macmillan, Basingstoke.

Borsch-Supan, A and Hajivassiliou, V A (1993) 'Smooth Unbiased Multivariate Probability Simulators for Maximum Likelihood Estimation of Limited Dependent Variable Models', Journal of Econometrics, 58, 347-368.

Brouwer E and Kleinknecht A (1996) 'Determinants of innovation: a microeconometric analysis of three alternative innovation output indicators', in A Kleinknecht, (ed.), Determinants of Innovation: the Message from New Indicators. London and Basingstoke: Macmillan Press.

Buckley, P J and Carter, M J (1999) 'Managing Cross Border Complementary Knowledge', International Studies of Management and Change, 29, 1, 80104.

Cockburn, I and Henderson, R (1998) 'Absorptive Capacity, Co-Authoring Behaviour and the Organisation of Research in Drug Discovery', Journal of Industrial Economics, 46, 157-182.

Cohen, W and Levithal, D (1989) 'Innovation and Learning: The Two Faces of R\&D', The Economic Journal, 99, 569-596. 
Davelaar E. and Nijkamp P (1992) 'Operational Models on Industrial Innovation and Spatial Development: A Case Study for the Netherlands', Journal of Scientific and Industrial Research, 51, 253-284.

Davelaar E. and Nijkamp P. (1989) 'Spatial Dispersion of Technological Innovation: A Case Study for the Netherlands By Means of Partial Least Squares', Journal of Regional Science, 29, 3, 325-346.

Dobkins, L H (1996) 'Location, innovation and trade: the role of localisation and nation-based externalities', Regional Science and Urban Economics, 26, 6, 591-612

Egelhoff, W G Gorman, L and McCormick, S (1998) 'Using Technology as a Path to Subsidiary Development', in Birkinshaw, J and Hood, N Multinational Corporate Evolution and Subsidiary Development, Macmillan, Basingstoke.

Freeman, C (1991) 'Networks of Innovators; A Synthesis of Research Issues', Research Policy, 20, 499-514.

Gans, J and Stern, S (1997) 'Incumbency and R\&D Incentives: Licensing the Gale of Destruction', Working Paper, MIT Sloan School of Management.

Gauvin, S (1995) 'Networks of Innovator: Evidence from Canadian Patents', Group Decision and Negotiation, 4, 411-428.

Gemser, G and Wijnberg, N M (1995) 'Horizontal Networks, Appropriability Conditions and Industry Life Cycles, Journal of Industry Studies, 2, 2, 129 140.

Gilley, K M and Rasheed, A (2000) 'Making More by Doing Less: An Analysis of Outsourcing and Its Effects on Firm Performance', Journal of Management, $26,4,763-790$.

Greene, W H (1997) Econometric Analysis, Macmillan, New York.

Hansen, N M (1990) 'Innovative Regional Milieux, Small Firms and Regional Development; Evidence from Mediterranean France', Annals of Regional Science, 24, 107-123.

Harris R. I. D. and Trainor M. (1995) 'Innovations and R\&D in Northern Ireland manufacturing: a Schumpeterian approach', Regional Studies, 29, 593-604.

Hay, D A and Morris, D J (1991) Industrial Economics and Organisation, $2^{\text {nd }}$ ed, Oxford University Press, Oxford.

Hertog, R G J den and Thurik A R (1993) 'Determinants of Internal and External R\&D: Some Dutch Evidence’ De Economist, 141, 279-89.

Karlsson, C (1997) 'Product Development, Innovation Networks, Infrastructure and Agglomeration Economies', Annals of Regional Science, 31, 235-258. 
Kleinknecht A. and Poot T. P. (1992) 'Do Regions Matter for R\&D?', Regional Studies, 32, 221-32.

Koopmans, T C (1957) 'Three Essays on the State of Economic Science', McGraw Hill, New York.

Koschatzky, K (1998) 'Firm Innovation and Region: The Role of Space in Innovation Processes', International Journal of Innovation Management, 2, 383-408.

Love, J H and Ashcroft, B (1999) "Market versus corporate structure in plant-level innovation performance", Small Business Economics, 13, 97-109.

Love, J H and Roper, S (1999) "The determinants of innovation: R\&D, technology transfer and networking effects", Review of Industrial Organisation, 15, 4364.

Love, J H and Roper, S (2000) "Scale, structure and R\&D mode: evidence from UK manufacturing”, NIERC Working Paper 41, Queen's University Belfast.

Love, J H and Roper, S (2001) "Location and Network Effects on Innovation Success: Evidence for UK, German and Irish Manufacturing Plants", Research Policy, 30, 645-663.

Love, J. H. (2001) "Patterns of Networking in the Innovation Process: A Comparative Study of the UK, Germany and Ireland", in O Jones, S Conway and F Steward (eds) Social Interaction and Organisational Change: Aston Perspectives on Innovation Networks, Imperial College Press, London.

Maddala, G S (1983) Limited-Dependent and Qualitative Variables in Econometrics, Cambridge University Press, Cambridge.

Mason, C and Wagner, K (1994) 'Innovation and the Skill Mix: Chemicals and Engineering in Britain and Germany', National Institute Economic Review, May, 61-72.

Morgan, K (1997) 'The Learning Region: Institutions, Innovation and Regional Renewal', Regional Studies, 31, 491-503.

Mowery, D C Oxley, J E and Silverman, B S (1996) 'Strategic Alliances and Interfirm Knowledge Transfer', Strategic Management Journal, 17, 77-91.

Oakey R. P. (1984) High Technology Small Firms: Innovative and Regional Development in Britain and the United States, Frances Pinter, London.

Oerlemans, L A G Meus, M T H and Boekema, F W M (1998) 'Do Networks Matter for Innovation? The Usefulness of the Economic Network Approach in Analysing Innovation', Tijdschrift voor Economische en Sociale Geografie, 89, 3, 298-309. 
Pavitt, K (1984) 'Sectoral Patterns of Technical Change: Towards a Taxonomy and a Theory’, Research Policy,13,6, 343-374.

Porter, M E (1990) The Competitive Advantage of Nations, Macmillan, London.

Roper, S (1997) 'Product Innovation and Small Business Growth: a Comparison of the Strategies of German, UK and Irish Companies', Small Business Economics, 9, 523-37.

Roper, S. (2001) 'Innovation, Networks and Plant Location: Some Evidence for Ireland', Regional Studies, forthcoming.

Roper, S, Ashcroft, B, Love, J H, Dunlop, S, Hofmann, H and Vogler-Ludwig K (1996) Product Innovation and Development in UK, Irish and German Manufacturing, Queen's University of Belfast/University of Strathclyde, Belfast and Glasgow.

Roper, S, Love, J H, Ashcroft, B, and Dunlop, S (2000) 'Industry and Location Effects on UK Plants' Innovation Propensity', Annals of Regional Science, 34, 489-502.

Rothwell, R and Dodgson, M (1994) 'Innovation and Size of Firm' in The Handbook of Industrial Innovation, Dodgson and Rothwell (eds), Edward Elgar, Aldershot.

Shefer, D and Frenkel, A (1998) 'Local Milieu and Innovations: Some Empirical Results', Annals of Regional Science, 32, 185-200.

Suarez-Villa, L and Karlsson, C (1996) 'The Development of Sweden's R\&Dintensive electronics industries: exports, outsourcing and territorial distribution', Environment and Planning A, 28, 783-817.

Suarez-Villa, L and Rama, R (1996) 'Outsourcing, R\&D and the Pattern of IntraMetropolitan Location; The Electronics Industries of Madrid', Urban Studies, 33, 7, 1155-1198.

Teece, D (1986) 'Profiting from Technological Innovation: Implications for Integration, Collaboration, Licensing and Public Policy', Research Policy, $15,285-305$.

Teece, D (1988) 'Technological Change and the Nature of the Firm' in G Dosi et al (eds) Technical Change and Economic Theory, Pinter, London.

Teece, D (1997) 'Economies of Scope and the Scope of the Enterprise' in Foss, N J (ed) Resources, Firms and Strategies, Oxford Management Readers, Oxford University Press.

Todtling F. (1992) 'Technological change at the regional level: the role of location, firm structure and strategy', Environment and Planning A, 24, 1565-1584. 
Veugelers, R and Cassiman, B (1999) 'Make and Buy in Innovation Strategies: Evidence from Belgian Manufacturing Firms', Research Policy, 28, 63-80.

Viming, A R and Globerman, S (1999) 'Contracting-out health care services: a conceptual framework', Health Policy, 46, 2, 77-96.

Williamson, O E (1975) Markets and Hierarchies: Analyses and Antitrust Implications, Free Press, New York. 